\title{
SMARTT
}

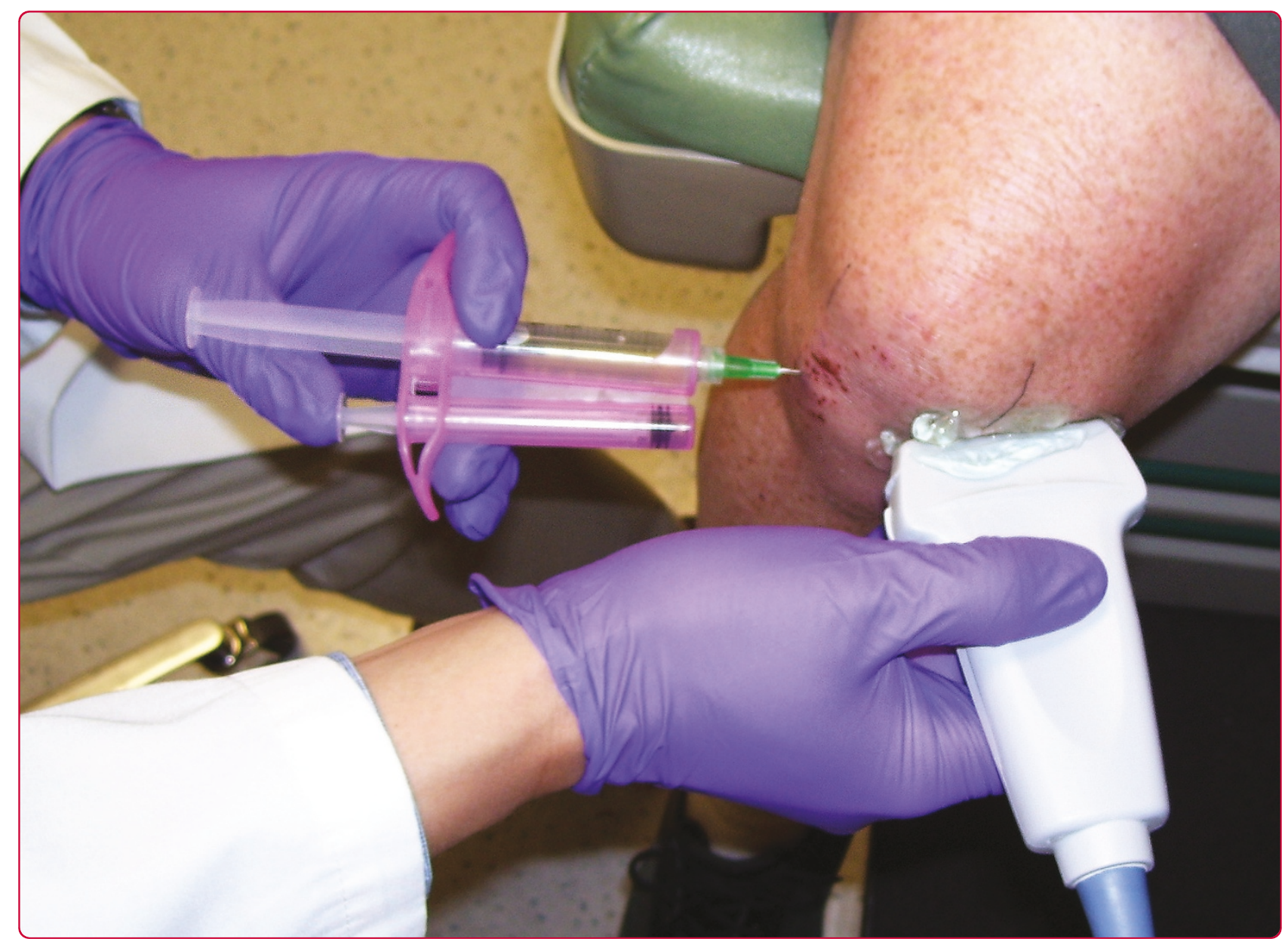

\section{The highly accurate anteriolateral portal for injecting the knee}

Chavez-Chiang et al. 


\title{
The highly accurate anteriolateral portal for injecting the knee
}

\author{
Colbert E Chavez-Chiang ${ }^{1 \dagger}$, Wilmer L Sibbitt $\mathrm{Jr}^{1{ }^{*}+}$, Philip A Band ${ }^{2 \dagger}$, Natalia R Chavez-Chiang ${ }^{1 \dagger}$, \\ Suzanne L DeLea ${ }^{1+}$ and Arthur D Bankhurst ${ }^{1+}$
}

\begin{abstract}
Background: The extended knee lateral midpatellar portal for intraarticular injection of the knee is accurate but is not practical for all patients. We hypothesized that a modified anteriolateral portal where the synovial membrane of the medial femoral condyle is the target would be highly accurate and effective for intraarticular injection of the knee.

Methods: 83 subjects with non-effusive osteoarthritis of the knee were randomized to intraarticular injection using the modified anteriolateral bent knee versus the standard lateral midpatellar portal. After hydrodissection of the synovial membrane with lidocaine using a mechanical syringe (reciprocating procedure device), $80 \mathrm{mg}$ of triamcinolone acetonide were injected into the knee with a 2.0-in $(5.1-\mathrm{cm})$ 21-gauge needle. Baseline pain, procedural pain, and pain at outcome (2 weeks and 6 months) were determined with the $10 \mathrm{~cm}$ Visual Analogue Pain Score (VAS). The accuracy of needle placement was determined by sonographic imaging.

Results: The lateral midpatellar and anteriolateral portals resulted in equivalent clinical outcomes including procedural pain (VAS midpatellar: $4.6 \pm 3.1 \mathrm{~cm}$; anteriolateral: $4.8 \pm 3.2 \mathrm{~cm} ; \mathrm{p}=0.77$ ), pain at outcome (VAS midpatellar: $2.6 \pm 2.8 \mathrm{~cm}$; anteriolateral: $1.7 \pm 2.3 \mathrm{~cm} ; \mathrm{p}=0.11$ ), responders (midpatellar: 45\%; anteriolateral: 56\%; $p$ $=0.33$ ), duration of therapeutic effect (midpatellar: $3.9 \pm 2.4$ months; anteriolateral: $4.1 \pm 2.2$ months; $p=0.69$ ), and time to next procedure (midpatellar: $7.3 \pm 3.3$ months; anteriolateral: $7.7 \pm 3.7$ months; $p=0.71$ ). The anteriolateral portal was $97 \%$ accurate by real-time ultrasound imaging.
\end{abstract}

Conclusion: The modified anteriolateral bent knee portal is an effective, accurate, and equivalent alternative to the standard lateral midpatellar portal for intraarticular injection of the knee.

Trial Registration: ClinicalTrials.gov: NCT00651625

\section{Background}

Intraarticular injection of the knee is the most common invasive procedure in sports medicine, accounting for approximately $39-64 \%$ of all outpatient joint procedures [1-10]. A number of anatomic landmark palpationguided intraarticular injection approaches to the knee are used including the extended leg lateral or medial midpatellar approaches and the bent knee lateral and medial anterior approaches [4,6,10-18]. While accessing the anteriolateral and anteriomedial portals with the patient in the sitting position with the knee bent, the

\footnotetext{
* Correspondence: wsibbitt@salud.unm.edu

† Contributed equally

'Department of Internal Medicine, University of New Mexico Health Sciences Center, Albuquerque, NM, USA

Full list of author information is available at the end of the article
}

target is traditionally the synovial membrane reflections in the intercondylar notch, but these approaches provide only $71-75 \%$ accuracy $[2,4,6,10-18]$. Although the extended leg lateral midpatellar approach has been reported to be highly accurate (93\%), there are certain patients where the midpatellar approach may be impractical [2]. A knee injection technique that permits the patient to remain in the sitting position with a bent knee, but provides similar levels of accuracy and outcome as the lateral midpatellar portal would be of clinical utility $[2,3,9]$.

We hypothesized that a modified anteriolateral portal where the synovial membrane of the medial femoral condyle is the needle target would be highly accurate and provide equivalent clinical outcomes as the standard

\section{Ciomed Central}


lateral midpatellar approach for intraarticular injection of the knee.

\section{Methods \\ Subjects}

This project was in compliance with the Helsinki Declaration, approved by the institutional review board (IRB), and is registered at ClinicalTrials.gov (Clinical Trial Identifier NCT00651625). Inclusion criteria included: 1) osteoarthritis of the knee; 2) Brandt grades 1-3 osteoarthritis as diagnosed by radiographs, 2) persistent pain in the involved joint, 3) significant pain in the involved joint by $10 \mathrm{~cm}$ Visual Analogue Pain Sale (VAS) where VAS $\geq 5 \mathrm{~cm}, 4$ ) failure of exercise and oral analgesics, and 5) the recommendation from the physician for an intraarticular injection $[9,19](6,50)$. Exclusion criteria included 1) Brandt grade 4 osteoarthritis, 2) hemorrhagic diathesis, 3) the use of warfarin or antiplatelet therapy, or 4) the presence of infection (6). A total of 83 knees with osteoarthritis were randomized between the lateral midpatellar portal (40 knees) and the modified anteriolateral portal (43 knees) (\% difference: $+8 \%$; $95 \%$ CI: $-8 \%$ to $+9 \%, \mathrm{p}=0.50$ ). Subject age (midpatellar: $61 \pm 10 \mathrm{yr}$; anteriolateral: $59 \pm 14 \mathrm{yr}$; \% difference: $-3 \%$; $95 \%$ CI: $-12 \%$ to $+6 \%, \mathrm{p}=0.47$ ), female gender (midpatellar: $80 \%$; anteriolateral: $88 \%$; \% difference: $+13 \%$; $95 \%$ CI: $-10 \%$ to $+31 \%$; $\mathrm{p}=$ $0.47)$, subjects who completed study $(100 \%$ for both, $\mathrm{p}=$ $0.5)$, and pre-procedure baseline pain (10 cm VAS; midpatellar: $8.1 \pm 2.0 \mathrm{~cm}$; anteriolateral: $7.6 \pm 2.2 \mathrm{~cm}$; \% difference: $-6 \%$; $95 \%$ CI: $-18 \%$ to $+5 \%$; $\mathrm{p}=0.28$ ) were similar between the two treatment groups. Outcomes included procedural pain and injection pain, significant pain (VAS $\geq 5 \mathrm{~cm}$ ), VAS pain scores at outcome (2 weeks and 6 months), mean change in VAS pain scores at outcome, responders (asymptomatic joints at outcome defined by VAS $<2 \mathrm{~cm}$ ), non-responders (symptomatic joints at outcome defined by VAS $\geq 2 \mathrm{~cm}$ ), duration of therapeutic effect (months), and time to reinjection or referral to surgery (months). Cost-effectiveness was not calculated because this is highly dependent on reimbursement that varies widely from country to country [20].

\section{Injection Technique}

The one-needle two-syringe technique was used where 1) one needle is used for anesthesia, arthrocentesis, hydrodissection, and intraarticular injection; 2) the first syringe is used to anesthetize, aspirate effusion, and hydrodissect and dilate the joint space, and 3) the second syringe is used to inject the intraarticular therapy [9]. For the modified anteriolateral portal, relevant anatomic landmarks (patella, patellar tendon, lateral tibial plateau, lateral femoral condyle, and medical femoral condyle were palpated and marked with ink (Figure 1 and 2). The anteriolateral portal was defined by the

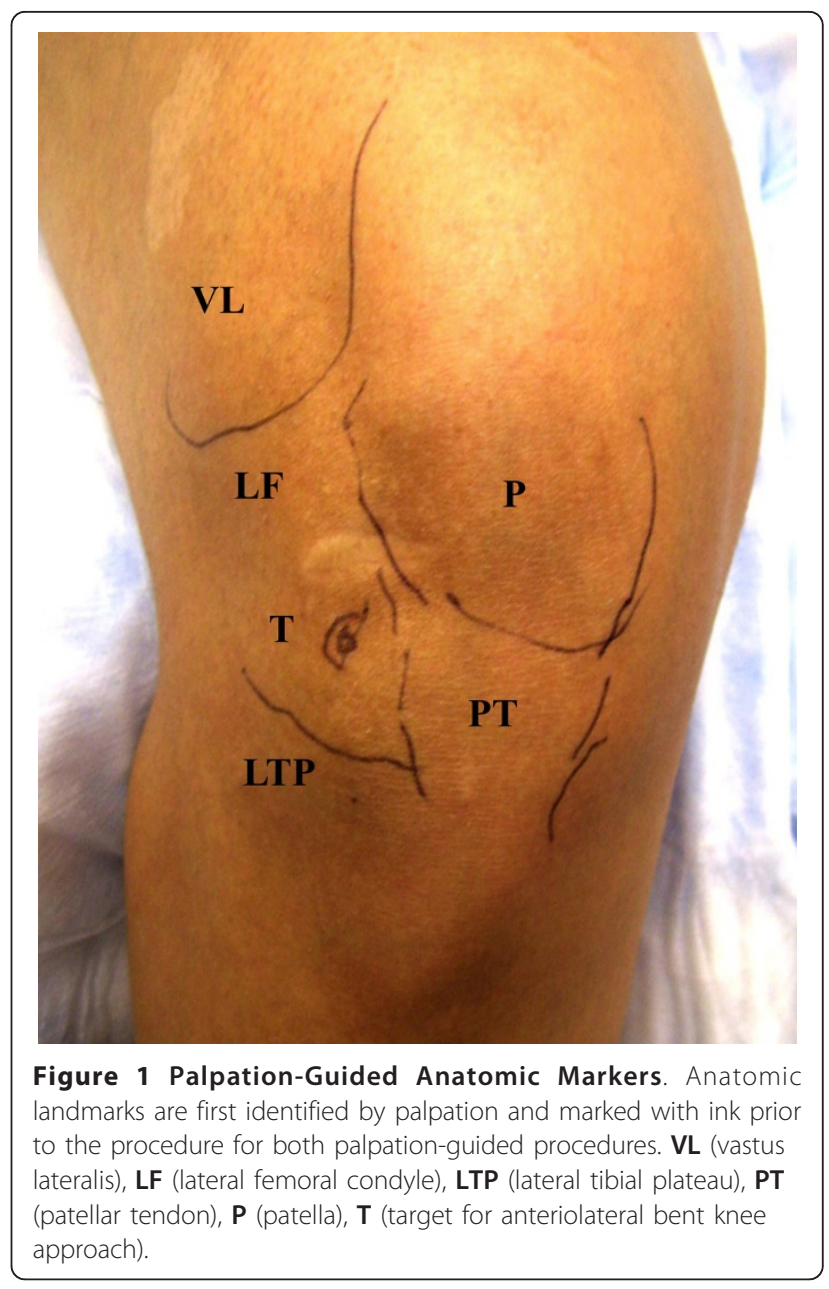

adjoining structures of inferiolateral border of the patellar, the patellar tendon, and the lateral tibial plateau. Rather than directing the needle to the traditional anteriolateral target, the intercondylar notch, the modified anteriolateral approach targets the synovial membrane of the medial femoral condyle (Figure 3 ) $[2,9,21]$. This requires directing the needle from the anteriolateral portal under the patellar tendon through the anterior fat pad, until the needle tip directly penetrates the synovial membrane and the bevel engages the medial femoral condyle (Figure 3) [9]. The lateral midpatellar injection was performed with the knee almost fully extended (in 10 to 15 degrees of flexion), and the needle was directed from the lateral surface of the knee to the middle of the patellofemoral joint (Figure 4) [2].

A 21 gauge 2.0 inch $(5.1-\mathrm{cm})$ needle $(305783-21 \mathrm{~g} \mathrm{BD}$ Needle, BD, 1 Becton Drive, Franklin Lakes, NJ 07417, website: http://www.bd.com) was mounted on a $3 \mathrm{ml}$ mechanical syringe, the reciprocating procedure device (RPD syringe) (AVANCA Medical Devices, Inc, Albuquerque, New Mexico, USA. website: http://www. AVANCAMedical.com). For very large individuals a 3.0 


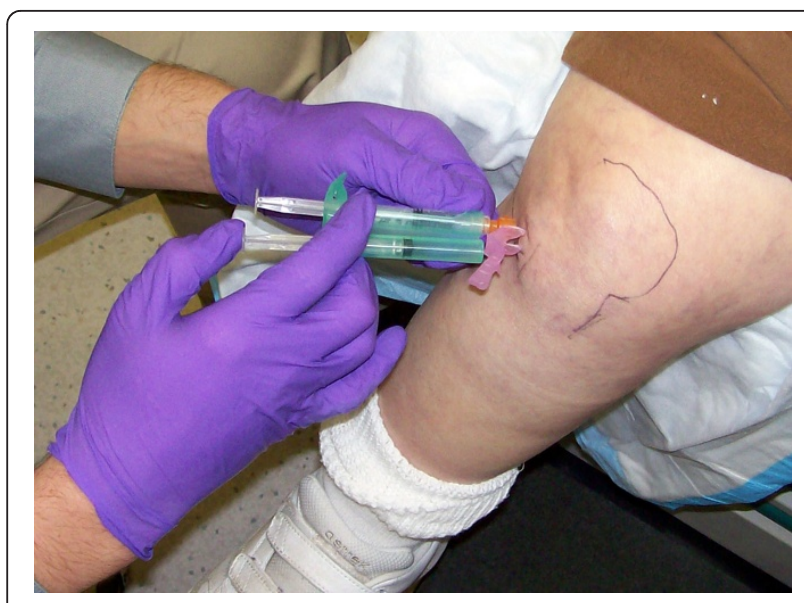

Figure 2 Introduction of the Needle from the Anteriolateral Portal. The reciprocating procedure device (RPD) control syringe is used with two hands to carefully introduce the needle and administer lidocaine. Depressing one plunger causes the RPD control syringe to aspirate and depressing the other causes the device to aspirate. If no fluid is obtained the needle is advanced to the medium femoral condyle.

inch $(7.7 \mathrm{~cm}) 21$ gauge needle was used instead. The RPD mechanical syringe is formed around the core of a conventional syringe barrel and plunger, but has a parallel injection plunger and an accessory barrel to control the motion of the injection plunger (Figure 2, 3, and 4). The two plungers are mechanically linked by a pulley in an opposing fashion, resulting in a set of reciprocating plungers. Thus, when the aspiration plunger is depressed with thumb, the mechanical syringe aspirates, and when the injection plunger is depressed with the thumb, the syringe injects. This permits the index and middle fingers

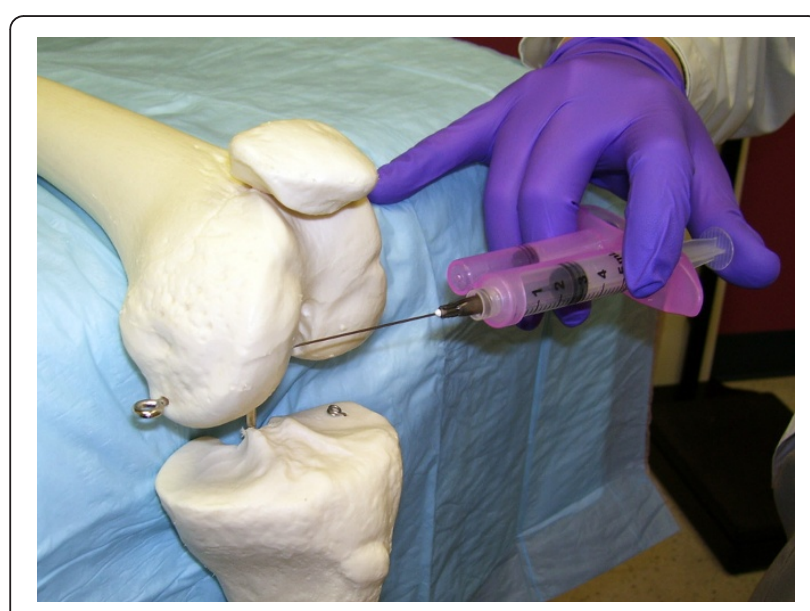

Figure 3 Modified Anteriolateral Portal. With the modified anteriolateral portal and the knee in the bent position, the needle is directed from the anteriolateral portal, under the patellar tendon, to the synovial surfaces of the medial femoral condyle rather than the intercondylar notch.

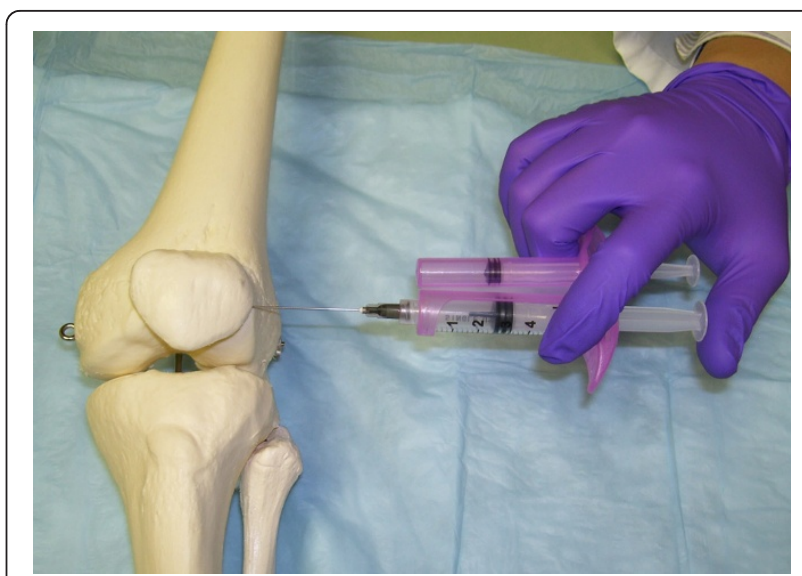

Figure 4 Lateral Midpatellar Portal. With the lateral midpatellar portal and the knee is almost fully extended, the needle is directed from the lateral midpatellar position into the patellofemoral joint space.

to remain in one position during both aspiration and injection, while the thumb only needs to move in a horizontal plane to the alternative plunger in order to change the direction of aspiration or injection. Mechanical syringes permit easy detection of small amounts of synovial fluid that flash back into the barrel confirming true intraarticular positioning [9,22-25]. Prior to the procedure the mechanical syringe was filled with $1 \%$ lidocaine (3 ml for the knee) (Xylocaine ${ }^{\circledR} 1 \%$, AstraZeneca Pharmaceuticals LP, 1800 Concord Pike, P.O. Box 15437, Wilmington, DE 19850-5437). While alternatively aspirating and injection, the needle tip was directed from the anteriolateral portal across the knee towards the medial femoral condyle until the needle tip penetrated the synovial membrane and the needle encountered firm resistance to further advance (Figure 2 and 3 ).

After the needle was advanced to the surface of the medial femoral condyle, the lidocaine was injected intraarticularly to hydrodissect and lift the synovial membrane over the needle bevel, and using one hand to hold the mechanical syringe and the other hand the needle hub, the mechanical syringe was rotated off the intraarticular needle, and a $3 \mathrm{ml}$ conventional syringe prefilled with $80 \mathrm{mg}$ triamcinolone acetonide suspension (Kenalog ${ }^{\circledR}$ 40, Westwood-Squibb Pharmaceuticals, Inc (Bristol-Myers Squibb), 345 Park Ave, New York, NY 10154-0004, USA) was rotated onto the intraarticular needle, and the treatment was injected. The needle was extracted, and firm pressure applied to the puncture site.

\section{Determination of Intraarticular Injection Accuracy}

To determine the intraarticular injection accuracy of the modified anteriolateral bent knee portal, 76 consecutive 
osteoarthritic knees fulfilling the above criteria were injected using the bent knee modified anteriolateral portal, and needle positioning and fluid flow determined by sonography. To determine accuracy of needle placement with sonography, the observer placed the long axis of the ultrasound transducer over the anteriomedial portion of the knee, such that the transducer was parallel to the needle shaft and thus the ultrasound beam vector would best approximate 90 degrees to the long axis of the needle, providing optimal reflected ultrasound signal and excellent visualization of the needle (Figure 5 and 6) [9]. A portable ultrasound unit with a $10-5 \mathrm{MHz}$ $38 \mathrm{~mm}$ broadband liner array transducer (Sonosite M-Turbo, SonoSite, Inc. 21919 30th Drive SE, Bothell, WA 98021) was used to sonographically determine the location of the medial femoral condyle, the position of the needle tip, intraarticular and extraarticular fluid flow, and dilation of the intraarticular space.

Two positions of the needle tip were tested: 1) when the needle palpably engaged the medial femoral condyle, and 2) when the needle did not palpably engage the medial fem femoral condyle. True intraarticular positioning was established by demonstrating the sonographic characteristics of the needle tip: 1) anatomic positioning of the needle tip at the interface of synovial membrane and cartilage (Figure 3 and 6), 2) demonstration of the free flow of fluid from the needle tip into the intraarticular space and not into the anterior fat pad (Figure 7), and 3) demonstration of dilation of the intraarticular space with the injected fluid [9,14,26-29] (Figure 7). Extraarticular injection was determined by observing 1) fluid movement into the anterior fat pad or retroflow of fluid back along the needle shaft, 2)

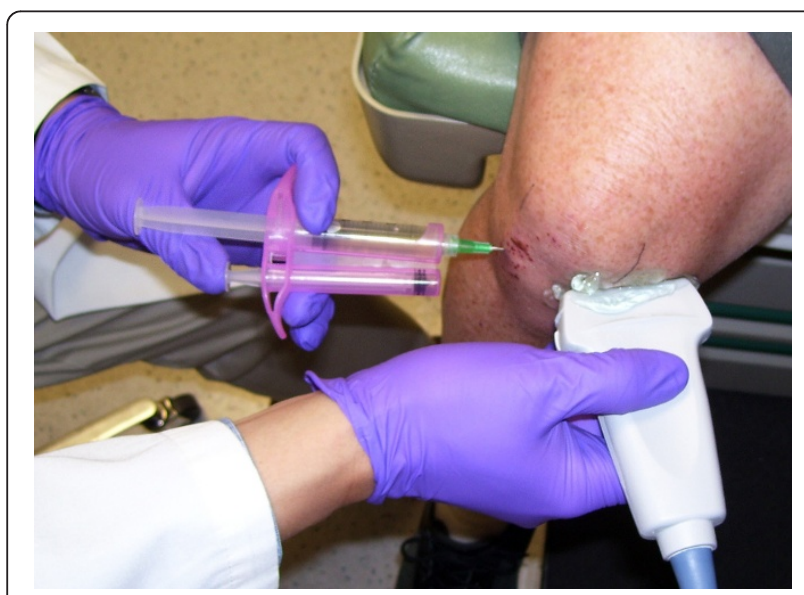

Figure 5 Placement of Ultrasound Probe. After introduction of the needle, the ultrasound probe is placed over the anteriomedial portal so that the ultrasound beam is at right angles to the needle shaft optimizing visualization of the location of the needle tip engaged to the medial femoral condyle.

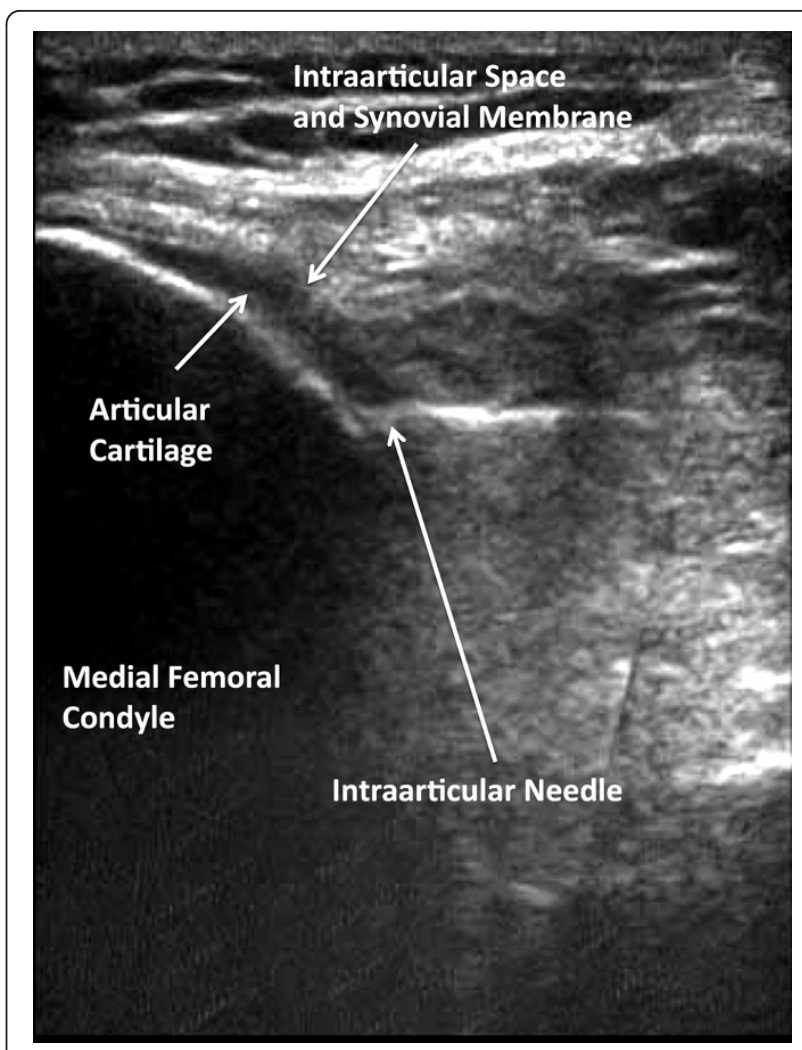

Figure 6 Sonographic Visualization of Needle Placement. The needle is advanced until the needle tip palpably engages the medial femoral condyle.

increased echogenicity in the septa of the anterior fat pad, and 3) lack of fluid movement into and dilation of the intraarticular space [9].

\section{Statistical Analysis}

Data were entered into Excel (Version 5, Microsoft, Seattle, WA), and analyzed in SAS (SAS/STAT Software, Release 6.11, Cary, NC). Differences in measurement data were determined with the student $\mathrm{t}$-test; categorical data were determined with Fisher's Exact Test, while differences between multiple parametric data sets were determined with Fishers Least Significant Difference Method.

\section{Results}

Table 1 demonstrates the similarities in short-term outcome between the lateral midpatellar and modified anteriolateral portals for injecting the knee. As can be, seen there were no differences in pre-procedure pain $(\mathrm{p}=$ $0.28)$, needle introduction pain $(p=0.77)$, significant needle introduction pain $(\mathrm{p}=0.74)$, injection pain $(\mathrm{p}=$ 0.92 ), or significant injection pain between the two portals $(\mathrm{p}=0.90)$. Table 2 demonstrates the intermediate (2 week) and long-term outcome (6 months). As can be 


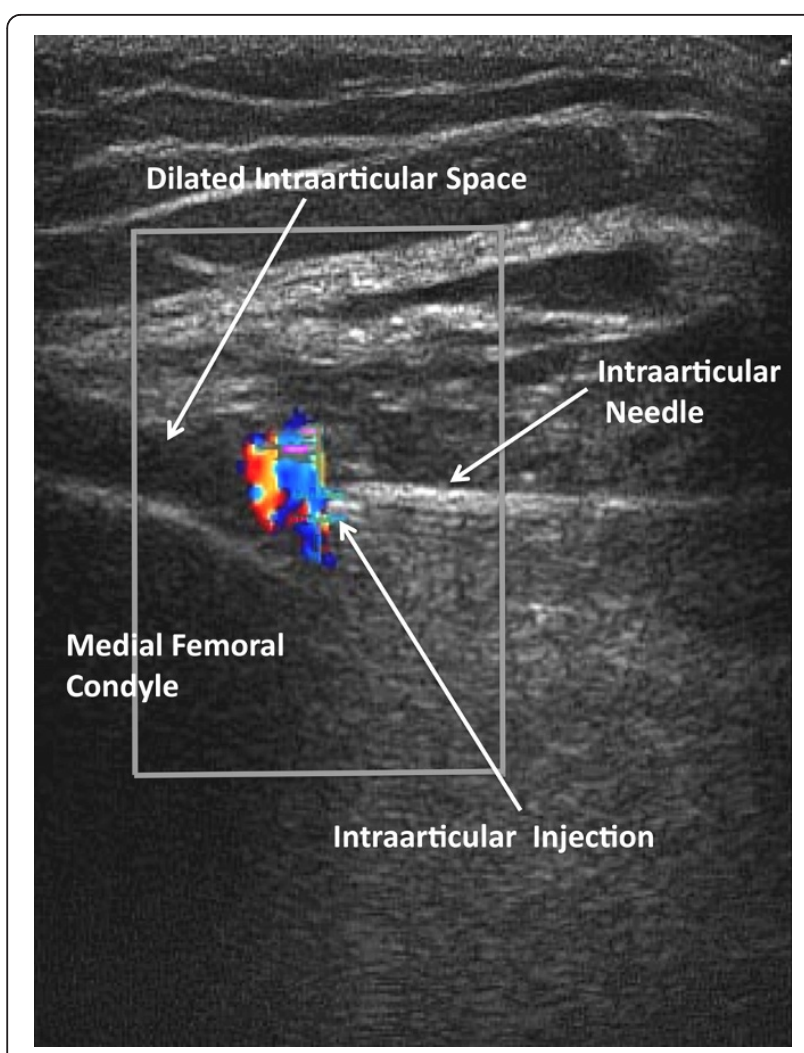

Figure 7 Sonographic Visualization of Direct Intraarticular Injection. After the needle tip is advanced until it palpably engages the medial femoral condyle, lidocaine is injected showing fluid movement into the intraarticular space and dilation of the intraarticular space. Here intraarticular movement of fluid is demonstrated by color Doppler at the needle tip with simultaneous dilation of the intraarticular space.

seen, there were no differences in pain at 2 weeks $(\mathrm{p}=$ $0.11)$, reduction in pain from baseline $(\mathrm{p}=0.13)$, responder rate $(\mathrm{p}=0.33)$, and non-responder rate $(\mathrm{p}=$ $0.33)$. There were also no differences in pain at 6 months $(p=0.89)$, duration of therapeutic effect $(p=0.69)$, or time to next procedure $(\mathrm{p}=0.71)$.

Accuracy of intraarticular injection using the bent knee modified anteriolateral portal was highly dependent on needle tip positioning. When the needle tip was not positioned to directly and palpably engage the medial femoral condyle, true intra-articular injection was only observed in $22 \%(17 / 76)$ of the test injections with the bulk of the injection being deposited in the anterior fat pad. When the needle was positioned so that it palpably engaged the medial femoral condyle, after hydrodissection with lidocaine, accurate intraarticular injection was demonstrated in $97 \%(74 / 76)$ of knees, resulting in a $+332 \%$ (95\% CI: $+289 \%$ to $+372 \%$ ) increase in intraarticular injection success, significantly better than when the needle was not positioned to engage the condyle $(\mathrm{p}<0.001)$. Although the 2 inch $(5.1 \mathrm{~cm})$ needle was used in the majority of subjects, the needle was hubbed or nearly hubbed against the skin in larger individuals in order to palpably engage the medial femoral condyle, thus, the use of the 3 inch $(7.7 \mathrm{~cm})$ needle or longer provided more leeway in large or obese individuals.

\section{Discussion}

The non-effusive or "dry joint" typical of osteoarthritis of the knee is particularly challenging to the sports medicine proceduralist, and selection of anatomic approach is of critical importance to ensure accuracy $[2,16,17,21]$. Several methods have been proposed to increase the accuracy of intraarticular placement of the needle in the absence of an effusion. These include careful selection of the anatomic portal, preinjection of air, saline or lidocaine to hydrodissect and dilate the intraarticular space, aspiration of droplets of synovial fluid or moisture into the barrel of the syringe, minimal retraction of the needle tip after palpable engagement of an articular cartilage or bone surface, use of highly controlled mechanical syringes, the one-needle two syringe technique, ultrasound guidance, or fluoroscopic injection of contrast material [2,4,6,9-18].

Jones et al demonstrated that only $66 \%$ of palpationguided knee injections were truly intraarticular, while Bliddal demonstrated that the superiolateral approach was $91 \%$ accurate $[11,13]$. In a study with 11 subjects in each arm, Toda et al demonstrated a that the modified

Table 1 Short-Term Outcomes for Intraarticular Injection of the Knee

\begin{tabular}{|c|c|c|c|c|c|}
\hline & $\begin{array}{l}\text { Lateral Midpatellar } \\
\text { Portal }\end{array}$ & $\begin{array}{l}\text { Modified Anteriolateral } \\
\text { Portal }\end{array}$ & & & \\
\hline Number of Subjects & 40 & 43 & $\begin{array}{c}\text { Percent } \\
\text { Difference }\end{array}$ & $\begin{array}{l}\text { 95\% Confidence } \\
\text { Interval }\end{array}$ & P Value \\
\hline Pre-Procedure Baseline Pain (VAS) & $8.1 \pm 2.0 \mathrm{~cm}$ & $7.6 \pm 2.2 \mathrm{~cm}$ & $-6 \%$ & $-18 \%$ to $+5 \%$ & 0.28 \\
\hline Needle Introduction Pain (VAS) & $4.6 \pm 3.1 \mathrm{~cm}$ & $4.8 \pm 3.2 \mathrm{~cm}$ & $+4 \%$ & $-26 \%$ to $+34 \%$ & 0.77 \\
\hline $\begin{array}{l}\text { Significant Needle Introduction Pain } \\
\text { (VAS } \geq 5 \mathrm{~cm} \text { ) }\end{array}$ & $48 \%(19 / 40)$ & $44 \%(19 / 43)$ & $-6 \%$ & $-49 \%$ to $+37 \%$ & 0.74 \\
\hline Injection Pain (VAS) & $2.8 \pm 2.8 \mathrm{~cm}$ & $2.9 \pm 3.4 \mathrm{~cm}$ & $+4 \%$ & $-45 \%$ to $+53 \%$ & 0.92 \\
\hline Significant Injection Pain (VAS $\geq 5 \mathrm{~cm}$ ) & $23 \%(9 / 40)$ & $21 \%(9 / 43)$ & $+2 \%$ & $-71 \%$ to $+86 \%$ & 0.90 \\
\hline
\end{tabular}


Table 2 Intermediate-Term and Long-Term Outcomes of IntraarticularInjection of the Knee

\begin{tabular}{|c|c|c|c|c|c|}
\hline & $\begin{array}{l}\text { Lateral Midpatellar } \\
\text { Portal }\end{array}$ & $\begin{array}{l}\text { Modified Anteriolateral } \\
\text { Portal }\end{array}$ & & & \\
\hline Number of Subjects & 40 & 43 & $\begin{array}{l}\text { Percent } \\
\text { Difference }\end{array}$ & $\begin{array}{l}95 \% \text { Confidence } \\
\text { Interval }\end{array}$ & $\begin{array}{l}\mathrm{P} \\
\text { Value }\end{array}$ \\
\hline Pain at Outcome (2 weeks) (VAS) & $2.6 \pm 2.8 \mathrm{~cm}$ & $1.7 \pm 2.3 \mathrm{~cm}$ & $-35 \%$ & $-78 \%$ to $+9 \%$ & 0.11 \\
\hline Reduction in Pain from Baseline (VAS) & $4.4 \pm 3.4 \mathrm{~cm}$ & $5.5 \pm 3.1 \mathrm{~cm}$ & $+25 \%$ & $-7 \%$ to $+57 \%$ & 0.13 \\
\hline Responders (VAS $<2 \mathrm{~cm}$ ) & $45 \%(18 / 40)$ & $56 \%(24 / 43)$ & +24 & $-23 \%$ to $+68 \%$ & 0.33 \\
\hline Non-Responders (VAS $\geq 2 \mathrm{~cm}$ ) & $55 \%(22 / 40)$ & $44 \%(19 / 43)$ & $-20 \%$ & $-56 \%$ to $+19 \%$ & 0.33 \\
\hline Pain at Outcome (6 months) (VAS) & $4.9 \pm 3.1 \mathrm{~cm}$ & $4.8 \pm 3.2 \mathrm{~cm}$ & $-2 \%$ & $-30 \%$ to $+26 \%$ & 0.89 \\
\hline Duration of Therapeutic Effect & $3.9 \pm 2.4$ months & $4.1 \pm 2.2$ months & $+5 \%$ & $-21 \%$ to $+31 \%$ & 0.69 \\
\hline $\begin{array}{l}\text { Time to Next Procedure (reinjection or } \\
\text { referral to surgery) }\end{array}$ & $7.3 \pm 3.3$ months & $7.7 \pm 3.7$ months & $+6 \%$ & $-16 \%$ to $+27 \%$ & 0.71 \\
\hline
\end{tabular}

Waddell approach (an anteriomedial approach with manipulative ankle traction at 30 degrees of knee flexion) was $100 \%$ accurate, bent knee anteriomedial approach was $55 \%$ accurate, and the anteriolateral approach was 55\% accurate [30]. Lopes et al reported $100 \%$ accuracy in knee injection rates, but these were in patients with rheumatoid arthritis where the target - the synovial mass (both tissue and effusions) - is much larger than in osteoarthritis [31]. In contrast, Cunnington et al reported only $66.3 \%$ accuracy in inflammatory arthritis with palpation-guided methods [32]. In a cadaver study Esenyel et al have demonstrated a 56\% to 85\% intraarticular injection accuracy depending on anatomic approach with the anteriolateral approach being the most accurate and the medial midpatellar portal being the least accurate [21]. Wind et al demonstrated that the superiomedial and superiolateral injections into the knee were the most accurate, while the lateral joint line injection was the most inaccurate [33]. Jackson et al demonstrated that lateral midpatellar approach was the most accurate (93\% accuracy) while the anteriomedial and anteriolateral portals were less accurate $(71 \%$ and $75 \%$, respectively) [2]. The target for the anteriolateral and anteriomedial portals is generally the intercondylar notch, which contains the cruciate ligaments and associated synovial membrane reflections $[2,21]$.

For those apprehensive individuals who involuntarily and forcefully contract the quadriceps muscles during a procedure, the elderly, individuals with knee contractures, the obese, or wheelchair-bound individuals, the lateral midpatellar approach can be difficult and/or inconvenient in these individuals. In addition since less subcutaneous fat is transversed by the needle in the lateral midpatellar portal, local complications of injections are more easily observed, including visible ecchymosis, hematoma, and cutaneous atrophy or foreign body granuloma formation at the puncture site caused by reflux of corticosteroid or hyaluron back through the needle tract [2,34-39]. Thus, refinement of a method of injecting the knee that permits the patient to remain in the sitting position with a bent knee and does not require forcing the needle into the constrained anatomy of the patellofemoral joint, but provides similar levels of accuracy as the lateral midpatellar portal would be of clinical utility in certain individuals $[2,21]$.

Because of the associated cruciate ligaments and reflections of the synovial membrane, the intercondylar notch presents a narrow anatomic target where the synovial space and the araeolar synovial tissue cannot be easily distinguished while advancing the needle tip, making true anatomic injection difficult, resulting in only a $71 \%$ to $75 \%$ accuracy rate [2]. We hypothesized that a modified anteriolateral portal where the synovial membrane overlying the medial femoral condyle is the needle target (Figure 3) would be accurate and provide equivalent clinical outcomes as the standard lateral midpatellar approach (Figure 4). The modified anteriomedial bent knee portal proved highly accurate (97\% intraarticular accuracy) when the needle tip could be felt engaging the medial femoral condyle, which compares favorably with the $93 \%$ accuracy with the lateral midpatellar approach [2]. Moreover, the modified bent knee anteriolateral portal provided equivalent clinical outcomes to the standard lateral midpatellar approach (Table 1 and 2).

There are limitations to this study. First, this study employed the one-needle two-syringe technique where a first syringe is used to anesthetize, aspirate, hydrodissect, and dilate the joint space. This technique may improve intraarticular accuracy and outcomes independent of anatomic portal because this maneuver in fact hydrodissects and lifts the synovial membrane over the needle bevel increasing true intraarticular injection accuracy [9]. Similarly, the one-needle two-syringe technique permits aspiration of synovial fluid prior to injection further confirming intraarticular injection accuracy, decompressing the joint, and improving outcomes as opposed to direct injection without aspiration that does not $[10,13,40,41]$. 
The present study used 1\% lidocaine for local anesthesia and hydrodissection. Although the local anesthetic bupivacaine has resulted in chondrolysis and malpractice actions, short-term exposure to low levels of lidocaine as used in this study have not been demonstrated to be chondrotoxic in vivo; furthermore, cases of chondrolysis with lidocaine have not been reported in large case series $[10,23,42-45]$. Lidocaine and chlorhexidine have the additional benefit in that they are potent bactericidal agents and may contribute to the low incidence of joint infections and lack of chondrolysis associated with intraarticular injections [23,36,46-49].

Another aspect of the modified anteriolateral injection technique is that a 2 to 3 inch $(5.1$ to $7.7 \mathrm{~cm})$ needle (depending on knee subcutaneous and skeletal dimensions) is necessary for this technique to be predictably accurate so that the needle tip can effectively access the joint space and palpably engage the medial femoral condyle. Since the 2 inch needle was hubbed or nearly hubbed in many individuals in order to palpably engage the medial femoral condyle, the use of the more common 1.5 inch $(3.8 \mathrm{~cm})$ needle would likely to substantially reduce the accuracy rates because the needle is too short to reach the synovial space overlying the medial femoral condyle and would only be useful in smaller individuals. Also the use of the mechanical syringe rather than a conventional syringe may have contributed to improved intraarticular accuracy independent of portal as mechanical syringes have been shown to be better controlled and more accurate than a conventional syringe, and reduce procedural trauma, accentuate synovial fluid detection and removal, and improve intraarticular injection outcomes with injection of local anesthetics, hyaluron, and corticosteroid [9,23-25,50-55].

\section{Conclusions}

In summary, the palpation-guided bent knee modified anteriolateral portal for intraarticular injection of the knee where the synovial space overlying the medial femoral condyle is the needle target is a highly accurate alternative method to the lateral midpatellar portal and provides high levels of accuracy with minimal pain while maintaining excellent injection outcomes.

\section{Acknowledgements and Funding}

There was no industry support for this study. All devices were purchased, not donated to this study.

\section{Author details}

${ }^{1}$ Department of Internal Medicine, University of New Mexico Health Sciences Center, Albuquerque, NM, USA. ${ }^{2}$ the Departments of Orthopaedic Surgery and Pharmacology, New York University Medical Center, New York, NY, USA.

\section{Authors' contributions}

CEC-C performed literatures searches, wrote part of the text, and contributed to the analysis and discussion. NRC-C and SLD performed many of the ultrasound studies and injection procedures, WLS, PAB, and ADB conceived the study, supervised the studies, analyzed data, and drafted the manuscript. All authors read and approved the final manuscript.

\section{Competing interests}

CEC-C, NRC-C, SLD, and ADB have nothing to disclose. PAB is an employee of New York University, and is a consultant to Smith \& Nephew, Inc., and Avanca Medical Devices, Inc. WLS is funded by Research Grant RO1 HLO77422-01-A3 from the US National Institutes of Health and by a Grant from the US Public Health Service. WLS also is an expert consultant for Intelligence Management Solutions, Inc., Ferring Pharmaceuticals, Inc., Avanca Medical Devices, Inc; Avasca, Inc., Becton-Dickinson, Inc., Surgin, Inc. and MediTech Duopross, Inc. WLS holds stock in Apple Inc, Celgene Corp, Inc, Avasca, Inc., Avanca, Inc, Sun Microsystems, Inc, Symantec Corp, and Java, Inc. In 2009 Abbott Vascular, Inc. acquired 4 patents invented by WLS but these patents are not relevant to the present research.

Received: 30 August 2010 Accepted: 30 March 2011

Published: 30 March 2011

\section{References}

1. Altman RD, Moskowitz R: Intraarticular sodium hyaluronate (Hyalgan) in the treatment of patients with osteoarthritis of the knee: a trial. Hyalgan Study Group. J Rheumatol 1998, 25:2203-12.

2. Jackson DW, Evans NA, Thomas BM: Accuracy of needle placement into the intra-articular space of the knee. J Bone Joint Surg Am 2002, 84A(9):1522-1527.

3. Jackson DW, Simon TM, Aberman HM: Symptomatic articular cartilage degeneration: the impact in the new millennium. Clin Orthop 2001, 391(Suppl):S14-25

4. Leopold SS, Redd BB, Warme WJ, Wehrle PA, Pettis PD, Shott S: Corticosteroid compared with hyaluronic acid injections for the treatment of osteoarthritis of the knee. A prospective, randomized trial. J Bone Joint Surg Am 2003, 85-A:1197-203.

5. Lussier A, Cividino AA, McFarlane CA, Olszynski WP, Potashner WJ, De Medicis R: Viscosupplementation with hylan for the treatment of osteoarthritis: findings from clinical practice in Canada. J Rheumatol 1996, 23:1579-85.

6. Neustadt DH: Intra-articular injections for osteoarthritis of the knee. Cleve Clin J Med 2006, 73:897-8, 901-4, 906-11.

7. Pyne D, loannou Y, Mootoo R, Bhanji A: Intra-articular steroids in knee osteoarthritis: a comparative study of triamcinolone hexacetonide and methylprednisolone acetate. Clin Rheumatol 2004, 23:116-20.

8. Schumacher HR, Chen LX: Injectable corticosteroids in treatment of arthritis of the knee. Am J Med 2005, 118:1208-14.

9. Sibbitt WL Jr, Peisajovich A, Michael AA, Park KS, Sibbitt RR, Band PA, Bankhurst AD: Does sonographic guidance influence the outcome of intraarticular injections? J Rheumatol 2009, 36:1892-902.

10. Weitoft T, Uddenfeldt P: Importance of synovial fluid aspiration when injecting intra-articular corticosteroids. Ann Rheum Dis 2000, 59:233-5.

11. Bliddal $\mathrm{H}$ : Placement of intra-articular injections verified by mini-air rthrography. Ann Rheum Dis 1999, 58:641-3.

12. Glattes RC, Spindler KP, Blanchard GM, Rohmiller MT, McCarty EC, Block J: A simple, accurate method to confirm placement of intra-articular knee injection. Am J Sports Med 2004, 32:1029-31.

13. Jones A, Regan M, Ledingham J, Pattrick M, Manhire A, Doherty M: Importance of placement of intra-articular steroid injections. BMJ 1993, 307:1329-30.

14. Qvistgaard E, Kristoffersen H, Terslev L, Danneskiold-Samsøe B, TorpPedersen S, Bliddal H: Guidance by ultrasound of intraarticular injections in the knee and hip joints. Osteoarthritis Cartilage 2001, 9:512-7.

15. Roberts W: Knee aspiration and injection. Phys Sports Med 1998, 26:93-4

16. Roberts WN: Primer: pitfalls of aspiration and injection. Nat Clin Pract Rheumatol 2007, 3:464-72.

17. Roberts WN, Hayes CW, Breitbach SA, Owen DS Jr: Dry taps and what to do about them: a pictorial essay on failed arthrocentesis of the knee. Am J Med 1996, 100:461-442

18. Waddell D, Estey D, Bricker DC, Marsala A: Viscosupplementation under fluoroscopic control. Am J Med Sports 2001, 3:237-41.

19. Brandt K, Fife R, Braunstein E, Katz B: Radiographic grading of the severity of knee osteoarthritis: relation of the Kellgren and Lawrence grade to a 
grade based on joint space narrowing and correlation with arthroscopic evidence of articular cartilage degeneration. Arthritis Rheum 1989, 32:1584-159.

20. U.S. Department of Health \& Human Services: Centers for Medicare \& Medicaide Services. Physician Fee Schedule Look-up. [http://www.cms. hhs.gov/PFSlookup/.

21. Esenyel C, Demirhan M, Esenyel M, Sonmez M, Kahraman S, Senel B, Ozdes T: Comparison of four different intra-articular injection sites in the knee: a cadaver study. Knee Surg Sports Traumatol Arthrosc 2007, 15:573-7.

22. Im SH, Lee SC, Park YB, Cho SR, Kim JC: Feasibility of sonography for intraarticular injections in the knee through a medial patellar portal. $J$ Ultrasound Med 2009, 28:1465-70

23. Moorjani GR, Bedrick EJ, Peisjovich A, Sibbitt WL Jr, Bankhurst AD: Integration of safety technologies into rheumatology and orthopedic practices A randomized controlled trial. Arthritis Rheum 2008, 58:1907-1914.

24. Nunez SE, Draeger HT, Rivero DP, Kettwich LG, Sibbitt WL Jr, Bankhurst AD: Reduced pain of intraarticular hyaluronate injection with the reciprocating procedure device. J Clin Rheumatol 2007, 13:16-9.

25. Sibbitt WL Jr, Sibbitt RR, Michael AA, Fu DI, Draeger HT, Twining JM, Bankhurst AD: Physician control of needle and syringe during traditional aspiration-injection procedures with the new reciprocating syringe. $J$ Rheumatol 2006, 33:771-8.

26. Delaunoy I, Feipel V, Appelboom T, Hauzeur JP: Sonography detection threshold for knee effusion. Clin Rheumatol 2003, 22:391-2.

27. Chu CR, Coyle CH, Chu CT, Szczodry M, Seshadri V, Karpie JC, Cieslak KM, Pringle EK: In vivo effects of single intra-articular injection of $0.5 \%$ bupivacaine on articular cartilage. J Bone Joint Surg Am 2010, 92:599-608.

28. Pendleton A, Millar A, O'Kane D, Wright GD, Taggart AJ: Can sonography be used to predict the response to intraarticular corticosteroid injection in primary osteoarthritis of the knee? Scand J Rheumatol 2008, 37:395-7.

29. Smith J, Finnoff JT, Henning PT, Turner NS: Accuracy of sonographically guided posterior subtaller joint injections: a comparison of 3 techniques. J Ultrasound Med 2009, 28:1549-57.

30. Toda Y, Tsukimura N: A comparison of intraarticular hyaluronan injection accuracy rates between three approaches based on radiographic severity of knee osteoarthritis. Osteoarthritis Cartilage 2008, 16:980-5,

31. Lopes RV, Furtado RN, Parmigiani L, Rosenfeld A, Fernandes AR, Natour J: Accuracy of intraarticular injections in peripheral joints performed blindly in patients with rheumatoid arthritis. Rheumatology (Oxford) 2008, 47:1792-4

32. Cunnington J, Marshall N, Hide G, Bracewell C, Isaacs J, Platt P, Kane D: A randomised, controlled, double blinded study of ultrasound guided corticosteroid joint injection in patients with inflammatory arthritis. Arthritis Rheum 2010, 62:1862-9.

33. Wind WM Jr, Smolinski RJ: Reliability of common knee injection sites with low-volume injections. J Arthroplasty 2004, 19:858-61.

34. Christensen L: Normal and pathologic tissue reactions to soft tissue gel fillers. Dermatol Surg 2007, 33(Suppl 2:):S168-75.

35. Dahl PR, Zalla MJ, Winkelmann RK: Localized involutional lipoatrophy: a clinicopathologic study of 16 patients. J Am Acad Dermatol 1996, 35:523-8.

36. Feldman JM, Chapin-Robertson K, Turner J: Do agents used for epidural analgesia have antimicrobial properties? Reg Anesth 1994, 19:43-7.

37. Jones KB, Patel PP, DeYoung BR, Buckwalter JA: Viscosupplementation pseudotumor. J Bone Joint Surg Am 2005, 87:1113-9.

38. Konttinen YT, Friman C, Tolvanen E, Reitamo S, Johansson E: Local skin rash after intraarticular methyl prednisolone acetate injection in a patient with rheumatoid arthritis. Arthritis Rheum 1983, 26:231-3.

39. Wiest $L G$, Stolz W, Schroeder JA: Electron microscopic documentation of late changes in permanent fillers and clinical management of granulomas in affected patients. Dermatol Surg 2009, 35(Suppl 2:):1681-8.

40. Tanaka N, Sakahashi H, Sato E, Hirose K, Ishima T, Ishii S: Intra-articular injection of high molecular weight hyaluronan after arthrocentesis as treatment for rheumatoid knees with joint effusion. Rheumatol Int 2002, 22:151-4.

41. Waddell DD, Marino AA: Chronic knee effusions in patients with advanced osteoarthritis: implications for functional outcome of viscosupplementation. J Knee Surg 2007, 20:181-4

42. Anderson SL, Buchko JZ, Taillon MR, Ernst MA: Chondrolysis of the glenohumeral joint after infusion of bupivacaine through an intra- articular pain pump catheter: a report of 18 cases. Arthroscopy 2010 26:451-61.

43. Busfield BT, Romero DM: Pain pump use after shoulder arthroscopy as a cause of glenohumeral chondrolysis. Arthroscopy 2009, 25:647-52.

44. Dragoo JL, Korotkova T, Kanwar R, Wood B: The effect of local anesthetics administered via pain pump on chondrocyte viability. Am J Sports Med 2008, 36:1484-8.

45. Grishko V, Xu M, Wilson G, Pearsall AW: Apoptosis and mitochondrial dysfunction in human chondrocytes following exposure to lidocaine, bupivacaine, and ropivacaine. J Bone Joint Surg Am 2010, 92:609-18.

46. Charalambous CP, Tryfonidis M, Sadiq S, Hirst P, Paul A: Septic arthritis following intra-articular steroid injection of the knee-a survey of current practice regarding antiseptic technique used during intra-articular steroid injection of the knee. Clin Rheumatol 2003, 22:386-90.

47. Farooq MA, Devitt AT: Perceived efficacy and risks of infection following intra-articular injections: a survey of orthopaedic surgeons. Ir J Med Sci 2005, 174:26-32.

48. Johnson SM, Saint John BE, Dine AP: Local anesthetics as antimicrobial agents: a review. Surg Infect (Larchmt) 2008, 9:205-13.

49. Best AJ, Nixon MF, Taylor GJ: Brief exposure of $0.05 \%$ chlorhexidine does not impair non-osteoarthritic human cartilage metabolism. J Hosp Infect 2007, 67:67-71.

50. Moorjani GR, Peisjovich A, Park KS, Sibbitt WL Jr, Bankhurst AD: Patient pain and tissue trauma during syringe procedures: A randomized controlled trial. J Rheumatology 2008, 35:1124-9.

51. Nunez SE, Bedrick EJ, Kettwich SC, Kettwich LG, Bankhurst AD, Sibbitt WL Jr: A randomized, controlled trial of the reciprocating procedure device for local anesthesia. J Emerg Med 2008, 35:119-25.

52. Bankhurst AD, Nunez SE, Draeger HT, Kettwich SC, Kettwich LG, Sibbitt WL $\mathrm{Jr}$ : A randomized controlled trial of the reciprocating procedure device for intraarticular injection of corticosteroid. J Rheumatol 2007, 34:187-92.

53. Michael AA, Moorjani GR, Peisajovich A, Park KS, Sibbitt WL Jr, Bankhurst AD: Syringe size: does it matter in physician-performed procedures? I Clin Rheumatol 2009, 15:56-60.

54. Sander O: Intra-articular corticosteroid injections with the reciprocating procedure device reduced procedural pain and duration more than the conventional syringe. Evid Based Med 2007, 12:106.

55. Draeger HT, Twining JM, Johnson CR, Kettwich SC, Kettwich LG Bankhurst AD: A randomised controlled trial of the reciprocating syringe in arthrocentesis. Ann Rheum Dis 2006, 65:1084-7.

doi:10.1186/1758-2555-3-6

Cite this article as: Chavez-Chiang et al:: The highly accurate

anteriolateral portal for injecting the knee. Sports Medicine, Arthroscopy, Rehabilitation, Therapy \& Technology 2011 3:6.

\section{Submit your next manuscript to BioMed Central and take full advantage of:}

- Convenient online submission

- Thorough peer review

- No space constraints or color figure charges

- Immediate publication on acceptance

- Inclusion in PubMed, CAS, Scopus and Google Scholar

- Research which is freely available for redistribution

Submit your manuscript at www.biomedcentral.com/submit
C Biomed Central 